\title{
Life history of the neon flying squid: effect of the oceanographic regime in the North Pacific Ocean
}

\author{
Taro Ichii ${ }^{1, *}$, Kedarnath Mahapatra $^{2}$, Mitsuo Sakai ${ }^{1}$, Yoshihiro Okada ${ }^{3}$ \\ ${ }^{1}$ National Research Institute of Far Seas Fisheries, 2-12-4 Fukuura, Kanazawa, Yokohama-city, Kanagawa 236-8648, Japan \\ ${ }^{2}$ Tokai University Frontier Ocean Research Center (T-FORCE), 3-20-1 Orido, Shimizu-ward, Shizuoka-city, \\ Shizuoka 424-8610, Japan \\ ${ }^{3}$ School of Marine Science and Technology, Tokai University, 3-20-1 Orido, Shimizu-ward, Shizuoka-city, \\ Shizuoka 424-8610, Japan
}

\begin{abstract}
The North Pacific Ocean population of the neon flying squid Ommastrephes bartramii, which undertakes seasonal north-south migrations, consists of autumn and winter-spring spawning cohorts. We examined life history differences between the 2 cohorts in relation to the oceanographic environment. The differences could be explained by seasonal north-south movements of the following 2 oceanographic zones: (1) the optimum spawning zone defined by sea surface temperatures; and (2) the food-rich zone defined by the position of the transition zone chlorophyll front (TZCF). The 2 cohorts use the food-rich zone in different phases of their life cycles. The spawning grounds for the autumn cohort occur within the subtropical frontal zone (STFZ), characterized by enhanced productivity in winter due to its proximity to the TZCF, whereas the spawning grounds for the winter-spring cohort occur within the subtropical domain, which is less productive. As the TZCF shifts northward in spring, the autumn cohort continues to occur in the productive area north of the TZCF, whereas the winter-spring cohort remains in the less productive area to the south until it migrates into productive waters north of the TZCF in the summer or autumn. Consequently, the autumn cohort grows faster than the winter-spring cohort during the first half of its life cycle, whereas the winter-spring cohort grows faster during the second half. This growth pattern may be responsible for differing migration patterns; males of the autumn cohort do not have to migrate given their early fast growth in the STFZ, whereas those of the winter-spring cohort must migrate to the food-rich subarctic frontal zone to compensate for their slow growth. These biological and ecological differences between the 2 cohorts suggest flexibility of their life history response to oceanographic environments.
\end{abstract}

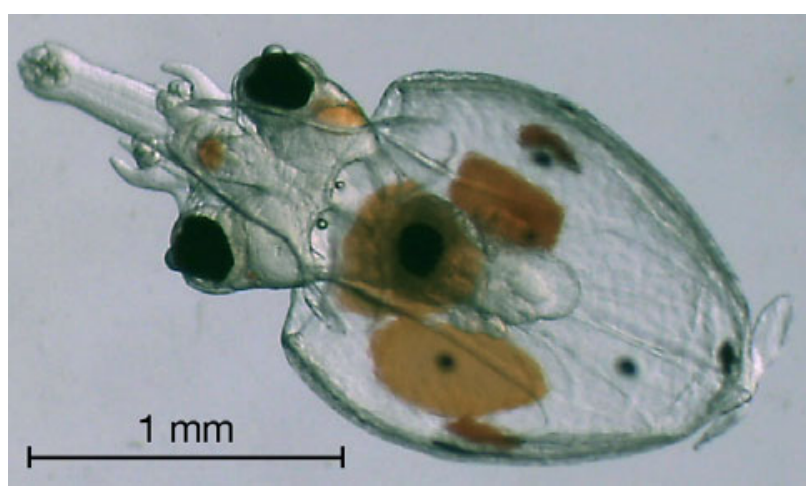

Hatchling of the neon flying squid Ommastrephes bartramii

Photo: M. Sakai

KEY WORDS: Neon flying squid - Red flying squid . Ommastrephes bartramii . Life history flexibility . Seasonal cohorts - Transition zone chlorophyll front . Subtropical frontal zone $\cdot$ Seasonal migration Resale or republication not permitted without
written consent of the publisher

\section{INTRODUCTION}

Life history flexibility in response to environmental variation is a key focus of ecological and evolutionary studies on squids (Boyle \& Rodhouse 2005), which are primarily characterized by semelparity (1 reproductive event per life) and a lifespan of approximately $1 \mathrm{yr}$ (O'Dor 1998). Many types of environmental variation can exert selective pressure for a longer reproductive life span, and semelparity is a risky option in uncertain environments (Stearns 1992). To compensate, squids 
produce multiple seasonal cohorts to disperse their offspring widely over time and space into different habitats (O'Dor 1998). Such a risk-spreading strategy to changing environments may result from being a short-lived species with a high turnover of generations, plastic growth, high mobility and wide variety of prey (Boyle \& Boletzky 1996).

The neon flying squid Ommastrephes bartramii (also known as red flying squid) is an oceanic squid that occurs worldwide in subtropical and temperate waters (Roper et al. 1984), and the North Pacific population comprises an autumn spawning cohort and a winterspring spawning cohort (Yatsu et al. 1997, 1998). The autumn cohort was the main target of an international large-scale driftnet fishery with annual catches of 100000 to $210000 \mathrm{t}$ during 1982 to 1992 (Ichii et al. 2006). After a moratorium was imposed on the use of large-scale driftnets, the winter-spring cohort became the main target of an international jigging fishery with annual catches reaching 100000 to $200000 \mathrm{t}$ during 1994 to 2004 (Chen et al. 2007, T. Ichii unpubl. data).

The autumn cohort corresponds to the 'extra large (LL) group' that hatches mainly from September to December, while the winter-spring cohort corresponds to the 'large (L), small (S) and extra small (SS) groups' that hatch mainly from November to May (Murakami et al. 1981, Murata 1990, Yatsu et al. 1997, Chen \& Chiu 2003). The LL group was initially believed to live for $2 \mathrm{yr}$, maturing and spawning in the second year, in contrast to the $1 \mathrm{yr}$ life span of the L and S groups. The SS group was even thought to consist of $1 \mathrm{yr}$ old individuals of the LL group (Murata 1990, Sinclair 1991). However, recent age estimations from statolith microstructure have shown that all groups have a 1 yr life span (Yatsu et al. 1997, Chen \& Chiu 2003).

Both the autumn and winter-spring cohorts migrate between spawning grounds in subtropical waters and feeding grounds in subarctic waters. However, 3 remarkable differences occur in life history characteristics between the 2 cohorts, although their causes are unknown: (1) the autumn cohort is rare in the western North Pacific Ocean, whereas the winter-spring cohort is widespread from the western to eastern North Pacific Ocean (Fig. 1, Murata et al. 1985, Yatsu et al. 1998, Ichii et al. 2006); (2) the autumn cohort grows faster during approximately the first half of its life cycle whereas the winter-spring cohort grows faster during the second half (Chen \& Chiu 2003, Ichii et al. 2004); (3) males and females of the autumn cohort follow separate migration patterns whereas those of the winterspring cohort follow nearly identical patterns (Murata \& Hayase 1993, Bower \& Ichii 2005). It is worth noting that the sex-segregated migration of the autumn cohort is suggested based on the migration route for females, which is already known, while that for males

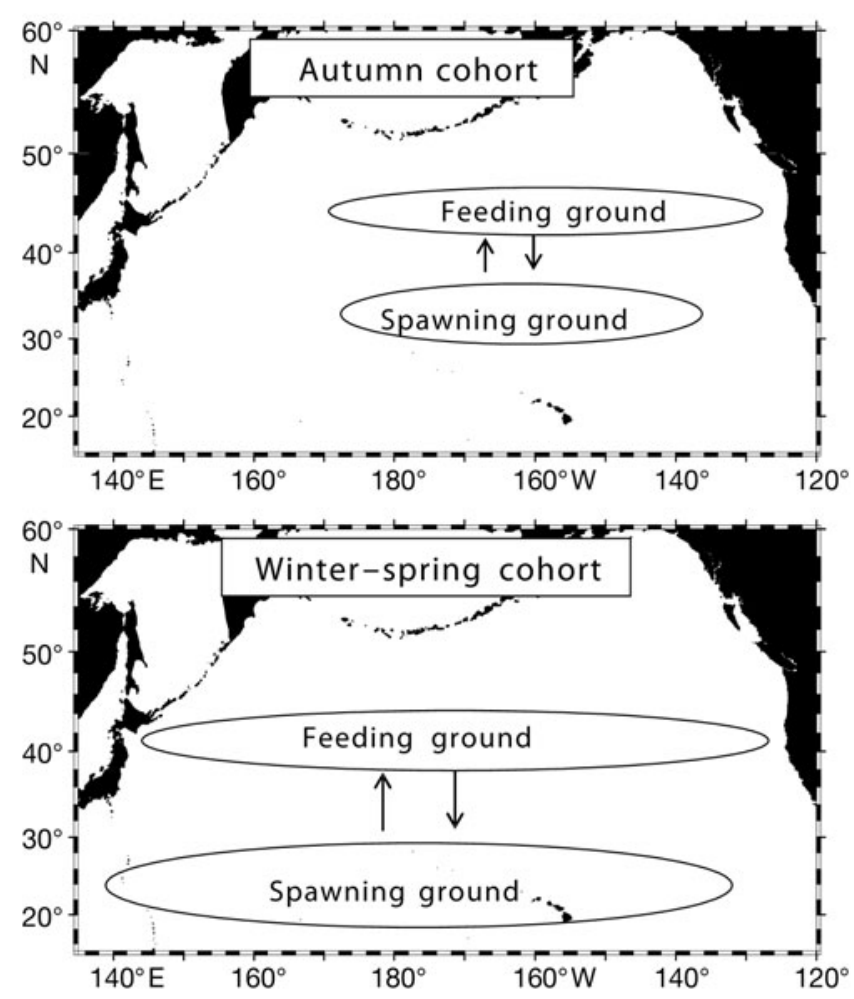

Fig. 1. Ommastrephes bartramii. Migration patterns of the autumn and winter-spring cohorts of neon flying squid in the North Pacific Ocean

is still unknown (Yatsu et al. 1997). These differences may result from environmental variations experienced by the cohorts during their life cycle.

In the present study, we examined the migration of each cohort in relation to seasonal changes in oceanographic environments to investigate possible causes for the 3 differences outlined above. We paid special attention to seasonal north-south movements of 2 oceanographic zones: the optimum spawning zone for this species defined by the sea surface temperature (SST) range of 21 to $25^{\circ} \mathrm{C}$ (Bower 1994, Ichii et al. 2004) and the foodrich zone defined by the position of the transition zone chlorophyll front (TZCF). The geographic acronyms used throughout this paper are listed in Table 1. The TZCF, which is indicated by the $0.2 \mathrm{mg} \mathrm{m}^{-3}$ surface chlorophyll $a(\mathrm{chl}$ a) concentration contour, is a zone of surface convergence where cool, high chl a surface waters from the north sink beneath warm, oligotrophic waters to the south, thereby probably concentrating food resources (Polovina et al. 2000, 2001, Baker et al. 2007).

\section{MATERIALS AND METHODS}

Oceanographic data. Monthly climatological temperature, salinity, chl $a$ and geostrophic current data were used to depict monthly variability of oceano- 
Table 1. Acronyms of oceanographic features used in the paper

\begin{tabular}{|ll|}
\hline Acronyms & Oceanographic features \\
\hline KEC & Kuroshio extension current \\
SAFZ & Subarctic frontal zone \\
STD & Subtropical domain \\
STFZ & Subtropical frontal zone \\
TZ & Transition zone \\
TZCF & Transition zone chlorophyll front \\
\hline
\end{tabular}

graphic features in the North Pacific Ocean. The $0.25^{\circ}$ gridded monthly climatological mean fields of temperature and salinity used in this study are from the World Ocean Atlas 2001 (WOA01) of the National Oceanographic Data Center (www.nodc.noaa.gov/OC5/ WOA01/qd_ts01.html). Documentation regarding these data sets as well as data statistics, analyses and compilation of in situ measurements made before 2001 are provided in Conkright et al. (2002a,b), Stephens et al. (2002) and Boyer et al. (2002, 2005). The subarctic frontal zone (SAFZ) and subtropical frontal zone (STFZ) are defined by the 7 to $10^{\circ} \mathrm{C}$ range at $100 \mathrm{~m}$ depth at ca. 40 to $45^{\circ} \mathrm{N}$ and the salinity range of 34.6 to 35.2 at $0 \mathrm{~m}$ at ca. 29 to $34^{\circ} \mathrm{N}$, respectively (Roden 1991).

The monthly Sea-viewing Wide Field-of-view Sensor (SeaWiFS) chl a climatology data used are products of the Ocean Biology Processing Group (OBGP), and the data were generated from SeaWiFS Ocean Reprocessing no. 5.2 (oceancolor.gsfc.nasa.gov/REPROCESSING/ SeaWiFS/R5.2/) completed in July 2007. The chl a climatology data were derived by time-binning the monthly binned files from September 1997 through August 2006 and mapping them to an equidistant cylindrical projection with $27 \mathrm{~km}$ resolution (ca. $0.25^{\circ}$ ) at the equator. Given that the available SeaWiFS data begin in September 1997, the climatology data from January to August were time-binned from 9 yr of monthly bins (1998 to 2006), and data from September to December were time-binned from $9 \mathrm{yr}$ of monthly bins (1997 to 2005).

Geostrophic currents were calculated based on the temperature and salinity data from WOA01 with a depth of $1500 \mathrm{~m}$ as the reference layer. The calculations were made using $0.25^{\circ}$ resolution data, but current vectors are shown on a $1^{\circ}$ latitude $\times 2^{\circ}$ longitude grid for clarity (see Fig. 3). The Generic Mapping Tools (GMT) software package was used to produce contour lines depicting the monthly distribution of sea surface temperature, salinity and chl a concentration as well as vectors depicting the geostrophic currents in the study region.

Squid migration. The principal data sources used were the published results of non-selective driftnet surveys conducted over the geographic range of the central and eastern North Pacific Ocean (35 to $46^{\circ} \mathrm{N}$, $170^{\circ} \mathrm{E}$ to $150^{\circ} \mathrm{W}$ ), where both the autumn and winterspring cohorts are distributed. These data were collected from May to November in 1984 to 1988 (Murata et al. 1985, 1989, Murata 1987, Murata \& Hayase 1993), and in May and August 1998 (Ichii et al. 2004). The driftnets used in the surveys consisted of 13 different mesh sizes (33 to $157 \mathrm{~mm}$ ) to eliminate mesh selectivity. At each driftnet site, 2 to 5 net panels of each mesh size ( 25 to 56 net panels in total) were deployed in the evening and retrieved at the following sunrise. Each panel was $50 \mathrm{~m}$ long and $7 \mathrm{~m}$ deep. Supplemental data sources included the published and unpublished results of exploratory jigging fisheries and jigging surveys in the central and eastern North Pacific Ocean (20 to $41^{\circ} \mathrm{N}, 170^{\circ} \mathrm{E}$ to $154^{\circ} \mathrm{W}$ ) during December to February 1980 (Yasui 1981, Yatsu 1992), February 1996 to 1999 (Young \& Hirota 1999), and October 1997 and May 1998 (T. Ichii unpubl. data).

Mantle length compositions by sex, month and latitude of immature and mature neon flying squid were used to determine the seasonal migration pattern of each cohort. We classified the mantle length compositions into the autumn (LL), winter (L) or spring (S and SS) cohorts according to Murata (1990). Peak months of spawning for the autumn, winter and spring cohorts were assumed to be October, December (Chen \& Chiu 2003) and March (Murata \& Hayase 1993), respectively. From hatching to 1 mo of age, the squid were considered to be paralarvae (Bigelow \& Landgraph 1993), and from 1 mo of age until they reach ca. $25 \mathrm{~cm}$ mantle length (ML), they were considered to be juveniles and subadults. This ML size was chosen because females and males of the winter-spring cohorts migrate together until they reach this size, after which they separate. This observation is based on the succession of ML composition by sex, month and latitude shown in the above principal and supplemental data sources.

\section{RESULTS}

\section{Oceanographic environments}

The optimum spawning SST range for neon flying squid undergoes seasonal movements to the south during winter and to the north in summer. In autumn (October), the optimum spawning SST range coincides with the STFZ in the central and eastern North Pacific Ocean, so the autumn spawning ground occurs in the STFZ (Fig. 2). During winter and spring (December to May), the optimum spawning SST range is located south of the STFZ across the North Pacific Ocean, indicating that the winter-spring cohort occurs in the subtropical domain (STD, Fig. 2). 


\section{: Unfavorable cold SST $\square$ : Optimum spawning SST}
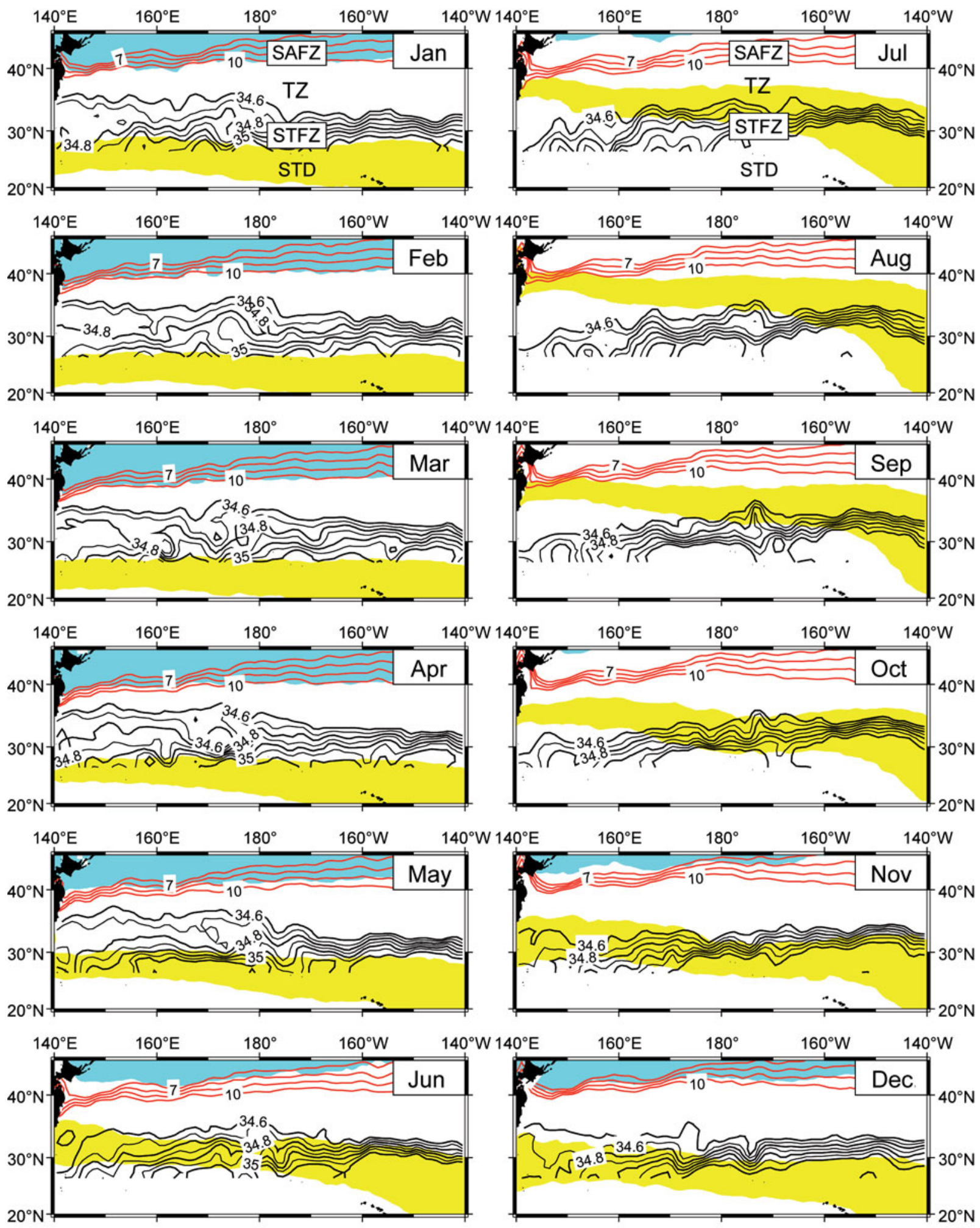

Fig. 2. Monthly climatological changes in optimum spawning sea surface temperature (SST) (21 to $\left.25^{\circ} \mathrm{C}\right)$ and unfavorable cold SST $\left(\leq 10^{\circ} \mathrm{C}\right)$ for neon flying squid in relation to the subarctic frontal zone (SAFZ) and subtropical frontal zone (STFZ). The SAFZ and STFZ are shown in the upper panels (January and July) by 7 to $10^{\circ} \mathrm{C}$ (temperature at $100 \mathrm{~m}$ ) contours (in red) and 34.6 to 35.2 (surface salinity) contours (in black). The transition zone (TZ) is between the SAFZ and STFZ. The subtropical domain (STD) is south of the STFZ 
Note that the optimum spawning SST range coincides with the strong Kuroshio Extension Current (KEC) that occurs at ca. $35^{\circ} \mathrm{N}$ in the western North Pacific Ocean during autumn (October, Fig. 3). The average eastward surface velocity components of the KEC at 33 to $37^{\circ} \mathrm{N}$ are $0.29,0.21$ and $0.15 \mathrm{~m} \mathrm{~s}^{-1}$ at 140 to $150^{\circ} \mathrm{E}, 150$ to $160^{\circ} \mathrm{E}$ and 160 to $170^{\circ} \mathrm{E}$, respectively. Thus, the current flows from ca. $140^{\circ} \mathrm{E}$ to ca. $170^{\circ} \mathrm{E}$ over $5 \mathrm{mo}$.

Distribution of the neon flying squid occurs at a zone above $10^{\circ} \mathrm{C} \mathrm{SST}$ (Ichii et al. 2006); hence, we characterized the zone with $\leq 10^{\circ} \mathrm{C} \mathrm{SST}$ as unfavorable for this species distribution. This SST zone covers the entire SAFZ during winter and early spring (January to April, Fig. 2). Even though the SAFZ is the main feeding area for this species during other seasons, it cannot exploit this productive zone during winter and early spring (January to April).

The TZCF marks the transition from lower chl a concentrations in the south to a more productive regime in the north. This front makes a seasonal north-south movement from the STFZ in the winter to the SAFZ in summer (Fig. 4). Hence, the STFZ (i.e. the autumn spawning/nursery ground) becomes a productive zone in winter (January to March), whereas the STD (i.e. the winter-spring spawning/nursery ground) remains less productive throughout the year. Furthermore, the $0.11 \mathrm{mg} \mathrm{m}^{-3}$ surface chl a concentration contour is located in the STFZ during late autumn and spring (November to May). This contour coincides approximately with the $20^{\circ} \mathrm{C} \mathrm{SST}$ front (Polovina et al. 2000), which is moderately productive (i.e. less productive than the TZCF, but more productive than the STD; Polovina et al. 2000, Seki et al. 2002). Thus, the productivity of the STFZ increases after late autumn (November).

\section{Migration}

The monthly latitudinal locations of the migration routes of both females and males are shown in relation to oceanographic variables averaged over the region bounded by $170^{\circ} \mathrm{E}$ to $150^{\circ} \mathrm{W}$ to depict the annual life cycle of different cohorts over a 1 yr period (Fig. 5). The migration route was constructed by connecting the representative latitudinal locations of spawning with the observed locations of each cohort. We assumed that the northward migrations of the autumn and winter cohorts start in accordance with increasing SST in the spawning/nursery grounds during April and that the spring cohort begins their migration following the paralarvae stage in May.

Female migrations are shown in Fig. 5a. The autumn cohort spawns in the STFZ, which is characterized by enhanced chl a concentrations in late autumn and winter due to the proximity of the $0.11 \mathrm{mg} \mathrm{m}^{-3} \mathrm{chl} a$ concentration contour and TZCF. Hence, juveniles and subadults in the STFZ during that period will experience enhanced chl a concentrations. Furthermore, as the TZCF moves northward in spring, the autumn cohort continues to occur in the productive area by migrating northward ahead of the TZCF. Consequently, it grows to ca. $35 \mathrm{~cm}$ ML by the time it arrives in the SAFZ in early summer. After remaining there during the summer, it migrates southward in the low chl $a$ area during early autumn. Its maximum body size at the spawning ground is ca. $45 \mathrm{~cm} \mathrm{ML.}$

Females of the winter-spring cohort spawn in the STD, which is less productive throughout the year (Fig. 5a). Hence, the juveniles never experience enhanced chl a levels. Furthermore, the winter-spring cohort migrates northward in the mostly low chl $a$ area and consequently, their body sizes are only ca. $25 \mathrm{~cm} \mathrm{ML} \mathrm{dur-}$ ing summer for the winter cohort and $20 \mathrm{~cm}$ in autumn for the spring cohort when they arrive in the SAFZ. After feeding in the productive SAFZ, they migrate southward in the high chl $a$ area on their way back to the spawning ground during autumn (for the winter cohort) and winter (for the spring cohort). Their maximum size is ca. $45 \mathrm{~cm}$ ML, which is the same as that of the autumn cohort.

Male migrations are shown in Fig. 5b. The observed locations for the autumn cohort were all in the STFZ. During extensive driftnet and jigging surveys, males were never found in waters north of $35^{\circ} \mathrm{N}$ between May and August, where and when females were migrating (note that very few surveys have been conducted for this species in waters south of $35^{\circ} \mathrm{N}$, including the STFZ, during this period. Males of the winter-spring cohort, however, migrate northward into the SAFZ together with females until this cohort grows to ca. $25 \mathrm{~cm}$ ML. After separating from the females, who continue migrating northward, males remain in the southern part of the SAFZ and then make their southward return migration a few months earlier than the females.

\section{DISCUSSION}

\section{Longitudinal distribution difference}

In autumn, the optimum spawning SST coincides with the KEC in the western North Pacific Ocean. The Kuroshio Current is the second strongest current in the world after the Gulf Stream and flows northeastward along the southern coast of Japan. It leaves the Japanese coast around latitude $35^{\circ} \mathrm{N}$ and turns eastward as the KEC into the central North Pacific Ocean. Spawned egg masses of ommastrephid squids are presumed to float for approximately $5 \mathrm{~d}$ near the thermocline (O'Dor \& Balch 1985, Sakurai et al. 1995, Sakurai 2002), and paralarvae and juveniles of the neon flying 


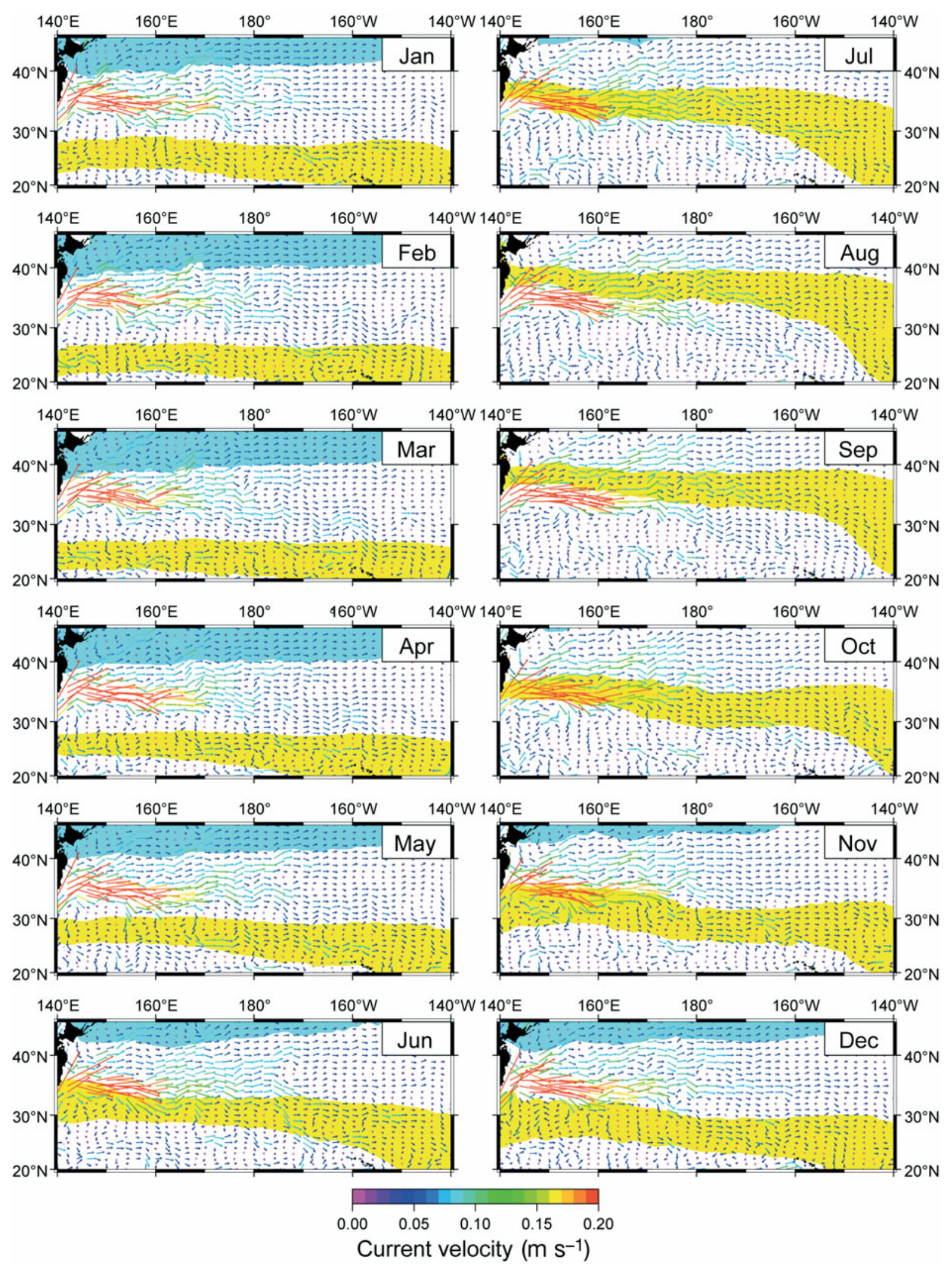

Fig. 3. Monthly climatological changes in optimum spawning SST (yellow zone) and unfavorable cold SST (blue zone) in relation to current vectors. Strong current vectors shown in red correspond to the Kuroshio Extension Current. Calculations for current vectors were made using $0.25^{\circ}$ resolution data, but current vectors are shown on a $1^{\circ}$ latitude $\times 2^{\circ}$ longitude grid for clarity 

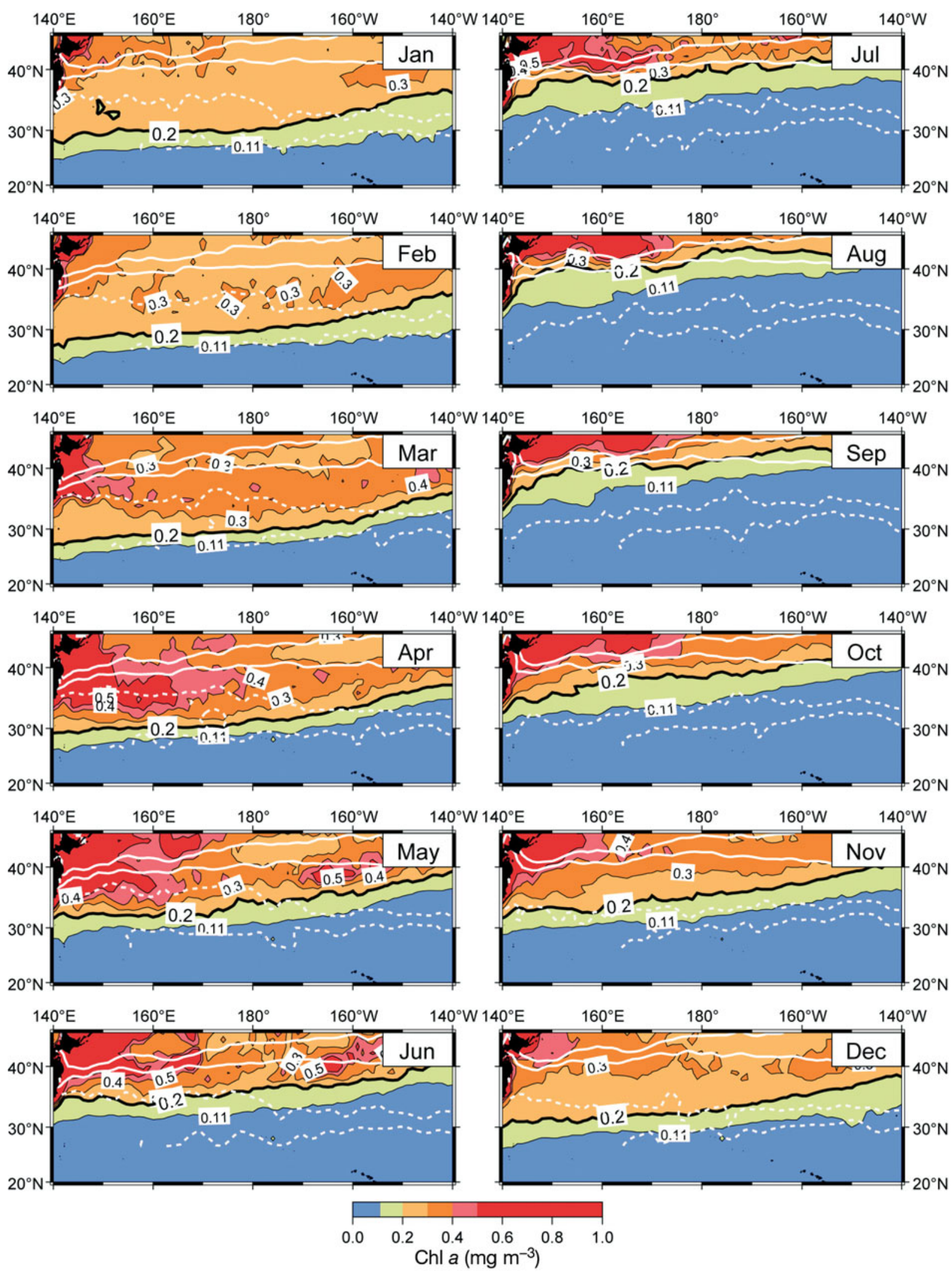

Fig. 4. Monthly climatological changes in SeaWiFS chl a concentrations $\left(\mathrm{mg} \mathrm{m}^{-3}\right)$. The bold black line indicates the transition zone chlorophyll front $\left(0.2 \mathrm{mg} \mathrm{m}^{-3}\right)$. The zone within the white solid lines indicates the subarctic frontal zone and that within the broken lines represents the subtropical frontal zone 

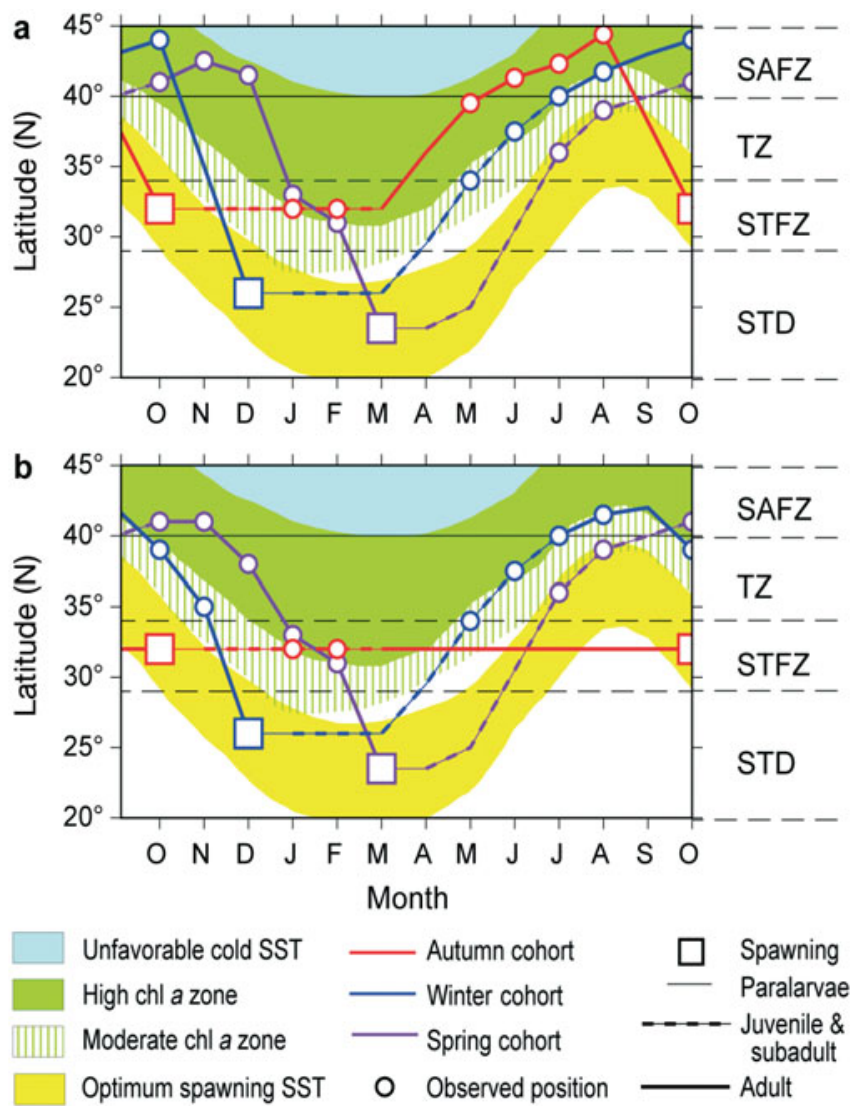

Fig. 5. Ommastrephes bartramii. Latitudinal migration of (a) females and (b) males of the autumn, winter and spring cohorts of neon flying squid in relation to oceanographic environments. SAFZ, TZ, STFZ and STD indicate the subarctic frontal zone, transition zone, subtropical frontal zone and subtropical domain, respectively. Squares indicate spawning locations and circles denote the locations of each cohort. 'Unfavorable cold SST' indicates an area of high chl a concentration but unfavorable cold SST. Zones of high chl $a$ and moderate chl a concentrations represent $\geq 0.2 \mathrm{mg} \mathrm{m}^{-3}$ and 0.11 to $0.2 \mathrm{mg} \mathrm{m}^{-3} \mathrm{chl}$ a concentrations, respectively

squid occur near the sea surface (Young \& Hirota 1990, Murata \& Nakamura 1998). If we assume that paralarvae and juveniles do not swim against the relatively rapid flowing KEC, even if spawning occurs in the western North Pacific Ocean during autumn (October), spawned squid would be carried to the central North Pacific Ocean by the time they start their northward migration. This is the likely reason for the rare occurrence of the autumn cohort in the western North Pacific Ocean.

\section{Growth pattern differences}

Based on the back-calculation method using statoliths, Chen \& Chiu (2003) estimated the daily growth rate (DGR, $\mathrm{mm} \mathrm{d}^{-1}$ ) of females of the autumn and winter cohorts for 10 and 8 mo after hatching, respectively. The autumn cohort exhibits a higher DGR than the winter cohort during the first 5 to 6 mo after hatching. However, both cohorts show similar DGRs at 7 to 8 mo of age. The autumn cohort then exhibits a sharply declining DGR at 9 to 10 mo of age. No estimation is available for the DGR of the winter cohort after 8 mo of age, but the winter cohort is expected to have a higher DGR than the autumn cohort at 8 to 12 mo since both cohorts have a similar maximum body size (ca. $45 \mathrm{~cm}$ $\mathrm{ML}$ ) at the time of spawning. This difference in growth patterns between the 2 female cohorts can be explained by different schedules in their use of high chl a habitat during their life cycles. The autumn cohort uses the productive habitat in the nursery ground, during northward migration and in the SAFZ, resulting in faster growth than seen in the winter-spring cohort during approximately the first half of its life cycle (Fig. 5). In contrast, the winter cohort uses the productive habitat in the latter phase of the northward migration, in the SAFZ and during the southward return migration, resulting in faster growth than observed in the autumn cohort during approximately the second half of its life cycle. The spawning/nursery ground for the winter cohort (i.e. STD) is characterized as an oligotrophic region where flux of nutrients into the euphotic zone is probably the lowest of any oceanic environment (Eppley \& Peterson 1979, Cullen 1982). This cohort achieves a high DGR, similar to that of the autumn cohort in June to July, when the former cohort reaches the productive TZCF. The spring cohort may follow a similar schedule in its use of the high chl a habitat as that of the winter cohort.

The area with high surface chl a concentrations near and north of the TZCF may be associated with a foodrich habitat for squid. In the nursery ground for the autumn cohort (i.e. the STFZ) during winter, its potential food (copepods and juvenile Pacific pomfret Brama japonica) are abundant where the SST ranges ca. 17 to $19^{\circ} \mathrm{C}$ (Seki \& Bigelow 1993, Young \& Hirota 1999), which is an area that closely corresponds to the TZCF (Bograd et al. 2004). Stomach fullness of the autumn cohort in spring during the northward migration tends to be significantly greater than in the winter-spring cohort in spring (Watanabe et al. 2004). The diet of the autumn cohort includes fishes (myctophids, Japanese anchovy Engraulis japonicus and Pacific saury Cololabis saira) and squids (boreal clubhook squid Onychoteuthis borealijaponica and the minimal armhook squid Berryteuthis anonychus) (Naito et al. 1977, Sinclair 1991, Arimoto \& Kawamura 1998, Watanabe et al. 2004). Many of these prey species migrate northward (Ogawa 1961, Kubodera 1986, Shimazaki 1986) in the high chl $a$ area ahead of the northward-moving TZCF, 
as in the case of the autumn cohort (Ichii et al. 2004). Thus, it appears the autumn cohort follows and exploits these migratory fishes and squids during its northward migration. The winter-spring cohort, in contrast, feeds on euphausiids and amphipods (Watanabe et al. 2004) that are considered to be endemic to the transition zone. Therefore, the high chl $a$ area may set the framework for an enhanced feeding regime for epipelagic nekton, compared with the low chl $a$ area.

The zone between the TZCF and the $0.11 \mathrm{mg} \mathrm{m}^{-3}$ surface chl a concentration contour corresponds to the fishing ground for swordfish Xiphias gladius, suggesting that it is a productive zone (Polovina et al. 2000). During winter, the $20^{\circ} \mathrm{C}$ SST front $\left(0.11 \mathrm{mg} \mathrm{m}^{-3} \mathrm{chl} \mathrm{a}\right.$ concentration contour is a proxy for this front) coincides with an increase in subsurface chl a concentration and, accordingly, a moderate increase in the integrated chl a concentration in the water column in this zone (Seki et al. 2002). The moderate enhancement in productivity of the STFZ due to the arrival of this zone in late autumn (November) may contribute to faster growth of the autumn cohort during November and December after the paralarvae period (Fig. 5).

Watanabe et al. (2008) indicated that a prey-rich environment is assured for the winter-spring cohort during its southward migration in the western North Pacific Ocean since the main prey species are abundantly distributed in the Kuroshio-Oyashio transition and Kuroshio regions during autumn and winter. Among the main species, myctophid fish (Ceratoscopelus warmingii, Tarletonbeania taylori and Diaphus theta) are widely distributed from the western to eastern North Pacific Ocean (Wisner 1976, Willis et al. 1988). Therefore, the winter-spring cohort in the present study region may exploit these species as well as southward-migrating small pelagic fishes (Pacific saury) and squids (boreal clubhook squid and the minimal armhook squid). Thus, the winter-spring cohort is believed to take advantage of the inferred abundant prey during its southward migration across the North Pacific Ocean.

\section{Male migration pattern differences}

Males of the winter-spring cohort separate from northward-migrating females when both males and females grow to ca. $25 \mathrm{~cm}$ ML. Considering that the minimum ML at maturity for males is approximately $28 \mathrm{~cm}$ (Yatsu et al. 1998), this may suggest that males have essentially attained the minimum size necessary for reproduction and further increase in size, via migration, is no longer a priority. With respect to the autumn cohort, we assumed similar behavior for the males. Chen \& Chiu (2003) estimated that the autumn cohort grows to ca. $25 \mathrm{~cm}$ ML as early as March, due to rapid growth at productive nursery grounds, so that males are assumed to separate from females afterward and continue to remain at the spawning/nursery ground (STFZ, Fig. 5b). This hypothesized migration route explains why males of the autumn cohort were never found north of $35^{\circ} \mathrm{N}$ despite the extensive study efforts. Sex segregated migration was also suggested for the closely related pelagic species of the subfamily Ommastrephinae, Sthenoteuthis oualaniensis, which forages in cooler but more productive peripheral regions and reproduces in the warmer central parts of its distributional regions (Nesis 1977). The main participants in the feeding migration are females, which reach considerably larger sizes than males, and males are not involved in prolonged migrations (Nesis 1977).

Size and sex-segregated migration may help males avoid cannibalism by large females (O'Dor \& Dawe 1998, Chen \& Chiu 2003). The mean size at maturity of the neon flying squid is ca. 30 to $33 \mathrm{~cm}$ ML for males and 40 to $55 \mathrm{~cm}$ for females (Yatsu et al. 1998), and females tend to be larger than males at the same age. This raises the possibility that the smaller males may be cannibalized by females unless the former separate from the latter. Furthermore, if swimming velocities are expressed as body lengths per second (Bartol et al. 2001), sex-segregated migration would also be dependent on the body size differences. However, quantitative information about swimming speeds of ommastrephid squids at various sizes is presently not available.

Males of the autumn cohort are considered to stay in the STFZ while females undertake their seasonal migration. This implies that the less productive STFZ during summer can provide enough food for newly mature males to reach their full mature size. Another advantage for staying in the STFZ would be that its frontal structure may facilitate meeting with returning females since the oceanic front plays an important role in accumulating mature squid (Ichii et al. 2004).

\section{Life history strategies}

The spawning season of the neon flying squid extends almost year-round (Yatsu et al. 1997), which could be a risk-spreading strategy to reduce the chances of population collapse by dispersing numerous seasonal cohorts into multiple environments. The autumn cohort appears to use the most favorable environment since it grows quickly to the size at which it matures. The winter-spring cohort, however, tends to cope with a less favorable environment since it grows more slowly to the same size, but it adapts to this environment by using a productive area in the latter half of its life cycle. The summer cohort is nonexistent or 
negligible, suggesting that this cohort suffers from the least favorable environment. One of the disadvantages for the summer cohort is that it cannot take advantage of the SAFZ during winter, its main feeding period, because the SAFZ is unfavorably cold during this time.

Yatsu et al. (1998) suggested that the autumn and winter-spring cohorts are not genetically independent because of their overlapping hatching dates. If this is correct, the ecological and biological differences between them indicate the great flexibility of the life history characteristics of the neon flying squid in response to different oceanographic environments.

Acknowledgements. We thank T. Namba for providing the current velocity data and M. Okazaki for help with the Generic Mapping Tools. We also thank K. Taki, H. Watanabe and T. Wakabayashi for their critical readings of the manuscript. The constructive comments and suggestions from 3 anonymous reviewers are greatly appreciated.

\section{LITERATURE CITED}

Arimoto Y, Kawamura A (1998) Characteristics of the fish prey of neon flying squid, Ommastrephes bartramii, in the central North Pacific. In: Report of the 1996 annual meeting on resources and fisheries on squids, National Research Institute of Far Seas Fisheries, Shizuoka, p 70-80 (in Japanese)

Baker JD, Polovina JJ, Howell EA (2007) Effect of variable oceanic productivity on the survival of an upper trophic predator, the Hawaiian monk seal Monachus schauinslandi. Mar Ecol Prog Ser 346:277-283

Bartol IK, Mann R, Patterson MR (2001) Aerobic respiratory costs of swimming in the negatively buoyant brief squid Lolliguncula brevis. J Exp Biol 199:3639-3653

Bigelow KA, Landgraph KC (1993) Hatch dates and growth of Ommastrephes bartramii paralarvae from Hawaiian waters as determined from statolith analysis. In: Okutani T, O'Dor RK, Kubodera $\mathrm{T}$ (eds) Recent advances in cephalopod fisheries biology. Tokai University Press, Tokyo, p 15-24

Bograd SJ, Foley DG, Schwing FB, Wilson C and others (2004) On the seasonal and interannual migration of the transition zone chlorophyll front. Geophys Res Lett 31:L17204. doi:10.1029/2004GL020637

Bower JR (1994) Distribution of paralarvae of the squid Ommastrephes bartramii near the Hawaiian Archipelago. MSc thesis, University of Hawaii, Honolulu

Bower JR, Ichii T (2005) The red flying squid (Ommastrephes bartramii): a review of recent research and the fishery in Japan. Fish Res 76:39-55

Boyer TP, Stephens C, Antonov JI, Conkright ME, Locarnini RA, O'Brien TD, Garcia HE (2002) World ocean atlas 2001 Vol 2: salinity. NOAA atlas NESDIS 50. US Government Printing Office, Washington, DC

Boyer TP, Levitus S, Garcia HE, Locarnini RA, Stephens C, Antonov JI (2005) Objective analyses of annual, seasonal, and monthly temperature and salinity for the World Ocean on a $0.25^{\circ}$ degree grid. Int J Climatol 25:931-945

Boyle PR, Boletzky SV (1996) Cephalopod populations: definition and dynamics. Philos Trans R Soc Lond B Biol Sci 351:985-1002
Boyle P, Rodhouse P (2005) Cephalopods: ecology and fisheries. Blackwell Publishing, Oxford

Chen C, Chiu T (2003) Variations of life history parameters in two geographical groups of the neon flying squid, Ommastrephes bartramii, from the North Pacific. Fish Res 63:349-366

Chen XJ, Zhao XH, Chen Y (2007) El Niño/La Niña influence on the western winter-spring cohort of neon flying squid (Ommastrephes bartramii) in the northwestern Pacific Ocean. ICES J Mar Sci 64:1152-1160

Conkright ME, Antonov JI, Baranova OK, Boyer TP and others (2002a) World ocean database 2001, Vol 1: introduction. US Government Printing Office, Washington, DC

Conkright ME, Locarnini RA, Garcia HE, O'Brien TD, Boyer TP, Stephens C, Antonov JI (2002b) World ocean atlas 2001: objective analyses, data statistics, and figures, CD-ROM documentation. National Oceanographic Data Center, Silver Spring, MD

Cullen JJ (1982) The deep chlorophyll maximum: comparing vertical profiles of chlorophyll a. Can J Fish Aquat Sci 39: 791-803

Eppley RW, Peterson EH (1979) Particulate organic matter flux and planktonic new production in the deep ocean. Nature 282:677-680

Ichii T, Mahapatra K, Sakai M, Inagake D, Okada Y (2004) Differing body size between the autumn and the winter-spring cohorts of neon flying squid (Ommastrephes bartramii) related to the oceanographic regime in the North Pacific: a hypothesis. Fish Oceanogr 13:295-309

Ichii T, Mahapatra K, Okamura H, Okada Y (2006) Stock assessment of the autumn cohort in the North Pacific based on past large-scale high sea driftnet fishery data. Fish Res 78:286-297

Kubodera T (1986) Relationships between abundance of epipelagic squids and oceanographic-biological environments in the surface waters of the subarctic Pacific in summer. Int North Pac Fish Comm Bull 47:215-228

Murakami K, Watanabe Y, Nakata J (1981) Growth, distribution and migration of flying squid (Ommastrephes bartramii) in the North Pacific. Res Inst North Pac Fish Hokkaido Univ Spec, Vol:161-179 (in Japanese with English summary)

Murata M (1987) Report on the fishery survey on flying squid by drift gillnetters, Shoyo-Maru, Kuromori-Maru No. 38 and Kanki-Maru No. 58, in the North Pacific in 1986. Document submitted to the annual meeting of the International North Pacific Fisheries Commission, Vancouver, Canada, October 1987. Fisheries Agency of Japan, Hokkaido Regional Fisheries of Japan, Hokkaido Regional Fisheries Research Laboratory, Hokkaido (in Japanese)

Murata M (1990) Oceanic resources of squids. Mar Behav Physiol 18:19-71

Murata M, Hayase S (1993) Life history and biological information on flying squid (Ommastrephes bartramii) in the North Pacific Ocean. Int North Pac Fish Comm Bull 53: $147-182$

Murata M, Nakamura Y (1998) Seasonal migration and diel migration of the neon flying squid, Ommastrephes bartramii, in the North Pacific. In: Okutani T (ed) International symposium on large pelagic squids. Japan Marine Fishery Resources Research Center, Tokyo, p 13-30

Murata M, Ishii M, Nakamura Y, Shingu C (1985) Distribution and population structure of Ommastrephes bartramii in the North Pacific. Report of 1984 annual meeting on resources and fisheries of squid. Hokkaido Reg Fish Res Lab, Hokkaido, p 76-85 (in Japanese)

Murata M, Nakamura Y, Saito H (1989) Report on the fishery 
survey on flying squid by Shoyo-Maru, Kanki-Maru No.3, Hoyo-Maru No.78 and Hokuho-Maru in the North Pacific in 1988. Document submitted to the annual meeting of the International North Pacific Fisheries Commission, Seattle, Washington, October 1989. Fisheries Agency of Japan, Hokkaido Regional Fisheries of Japan, Hokkaido Regional Fisheries Research Laboratory, Hokkaido (in Japanese)

Naito M, Murakami K, Kobayashi T (1977) Growth and food habits of oceanic squids (Ommastrephes bartramii, Onycho?teuthis borealijaponica, Berryteuthis magister and Gonatopsis borealis) in the western Subarctic Pacific region. Res Inst North Pac Fish Hokkaido Univ Spec Vol:339-351 (in Japanese with English summary)

Nesis KN (1977) Population structure of the squid Sthenoteuthis oualaniensis (Lesson, 1830) (Ommastrephidae) in the tropical western Pacific Ocean. In: Sweeney M (compiler) English translations of selected publications on cephalopods by Kir N. Nesis, Vol 1 Part 2 1965-1994, Smithsonian Institutions Libraries (2003), Washington, DC, p 439-456

O'Dor RK (1998) Can understanding squid life-history strategies and recruitment improve management? S Afr J Mar Sci 20:193-206

O'Dor RK, Balch N (1985) Properties of Illex illecebrosus egg masses potentially influencing larval oceanographic distribution. Northwest Atl Fish Organ Sci Counc Stud 9:69-76

O'Dor RK, Dawe EG (1998) Illex illecebrosus. In: Rodhouse PG, Dawe EG, O'Dor RK (eds) Squid recruitment dynamics. FAO Fish Tech Pap 376, Rome, p 77-104

Ogawa T (1961) Study on the fishes of the family Myctophidae in the northeastern sea area along the Pacific coast of Japan. Part 1. Species and distribution. Bull Tohoku Reg Fish Res Lab 19:81-89 (in Japanese with English Abstract)

Polovina JJ, Kobayashi DR, Parker DM, Seki MP, Balazs GH (2000) Turtles on the edge: movement of loggerhead turtles (Caretta caretta) along oceanic fronts spanning longline fishing grounds in the central North Pacific, 1997-1998. Fish Oceanogr 9:71-82

Polovina JJ, Howell E, Kobayashi DR, Seki MP (2001) The Transition Zone Chlorophyll Front, a dynamic, global feature defining migration and forage habitat for marine resources. Prog Oceanogr 49:469-483

Roden GI (1991) Subarctic-subtropical transition zone of the North Pacific: large-scale aspects and mesoscale structure. NOAA Natl Mar Fish Serv Tech Rep 105:1-38

Roper CFE, Sweeney MJ, Nauen CE (1984) FAO species catalogue. Vol 3: cephalopods of the world. An annotated and illustrated catalogue of species of interest to fisheries. FAO Fish Synop 125, Rome

Sakurai Y (2002) An experimental biological study of the reproductive mechanism of Japanese common squid, Todarodes pacificus. Nippon Suisan Gakkaishi 68:301-304 (in Japanese)

Sakurai Y, Young RE, Hirota J, Mangold K, Vecchione M, Clarke MR, Bower J (1995) Artificial fertilization and development through hatching in the oceanic squids Ommastrephes bartramii and Sthenoteuthis oualaniensis (Cephalopoda: Ommastrephidae). Veliger 38:185-191

Seki MP, Bigelow KA (1993) Aspects of the life history and ecology of the Pacific pomfret Brama japonica during win-

Editorial responsibility: Otto Kinne,

Oldendorf/Luhe, Germany ter occupation of the Subtropical Frontal Zone. Int North Pac Fish Comm Bull 53:273-283

Seki MP, Polovina JJ, Kobayashi DR, Bidigare RR, Mitchum GT (2002) An oceanographic characterization of swordfish (Xiphias gladius) longline fishing grounds in the springtime subtropical North Pacific. Fish Oceanogr 11:251-266

Shimazaki K (1986) Distribution of the pelagic fish community around the subarctic boundary in the North Pacific Ocean. Int North Pac Fish Comm Bull 47:247-264

Sinclair EH (1991) Review of the biology and distribution of the neon flying squid (Ommastrephes bartramii) in the North Pacific Ocean. NOAA Natl Mar Fish Serv Tech Rep 105:57-76

Stearns SC (1992) The evolution of life histories. Oxford University Press, Oxford

Stephens C, Antonov JI, Boyer TP, Conkright ME, Locarnini RA, O'Brien TD, Garcia HE (2002) World ocean atlas 2001 Vol 1: temperature. NOAA atlas NESDIS 49, US Government Printing Office, Washington, DC

> Watanabe H, Kubodera T, Ichii T, Kawahara S (2004) Seasonal change in feeding habits of the neon flying squid Ommastrephes bartramii in the transitional region of the Central North Pacific. Mar Ecol Prog Ser 266:173-184

Watanabe H, Kubodera T, Ichii T, Sakai M, Moku M, Masaki S (2008) Diet and sexual maturation of the neon flying squid Ommastrephes bartramii during autumn and spring in the Kuroshio-Oyashio transition region. J Mar Biol Assoc UK 88:381-389

Willis JM, Pearcy WG, Parin NV (1988) Zoogeography of midwater fishes in the subarctic Pacific. Bull Ocean Res Inst Univ Tokyo 26(Part II):79-142

Wisner RL (1976) The taxonomy and distribution of lanternfishes (family Myctophidae) of the eastern Pacific Ocean. Navy Ocean Research and Development Activity NORDA Report no. 3, Bay St Louis, MS

Yasui K (1981) Report of a feasibility study on the development of squid jigging grounds in North Pacific in 1979. Japan Marine Fishery Resources Research Center, Tokyo (in Japanese)

Yatsu A (1992) Distribution of flying squid, Ommastrephes bartramii, in the North Pacific based on a jigging survey, 1976-83. Bull Natl Res Inst Far Seas Fish 29:13-37 (in Japanese with English summary)

Yatsu A, Midorikawa S, Shimada T, Uozumi Y (1997) Age and growth of the neon flying squid, Ommastrephes bartramii, in the North Pacific Ocean. Fish Res 29:257-270

Yatsu A, Tanaka H, Mori J (1998) Population structure of the neon flying squid, Ommastrephes bartramii, in the North Pacific Ocean. In: Okutani T (ed) International symposium on large pelagic squids. Japan Marine Fishery Resources Research Center, Tokyo, p 31-48

Young RE, Hirota J (1990) Description of Ommastrephes bartramii (Cephalopoda: Ommastrephidae) paralarvae with evidence for spawning in Hawaiian waters. Pac Sci 44: 71-80

Young RE, Hirota J (1999) Year 3 progress report and a request for supplemental funds for year 4. Aspects of the ecology of the red squid Ommastrephes bartramii, a potential target for a major Hawaiian fishery. www.soest. hawaii.edu/PFRP/pdf/young99.pdf (accessed 6 June 2008)

Submitted: June 9, 2008; Accepted: December 3, 2008

Proofs received from author(s): February 24, 2009 